Portland State University

PDXScholar

1985

\title{
A study using the 10-key pad on a microcomputer and electronic calculator
}

Nancy K. Pechman

Portland State University

Follow this and additional works at: https://pdxscholar.library.pdx.edu/open_access_etds

Part of the Educational Assessment, Evaluation, and Research Commons Let us know how access to this document benefits you.

Recommended Citation

Pechman, Nancy K., "A study using the 10-key pad on a microcomputer and electronic calculator" (1985). Dissertations and Theses. Paper 3530.

https://doi.org/10.15760/etd.5414

This Thesis is brought to you for free and open access. It has been accepted for inclusion in Dissertations and Theses by an authorized administrator of PDXScholar. Please contact us if we can make this document more accessible: pdxscholar@pdx.edu. 
AN ABSTRACT OF THE THESIS of Nancy K. Pechman for the Master of Science in Teaching in Business Education presented July 31, 1985.

Title: A Study Using the 10-Key Pad on a Microcomputer and Electronic Calculator

\section{APPROVED BY MEMBERS OF THE THESIS COMMITTEE:}
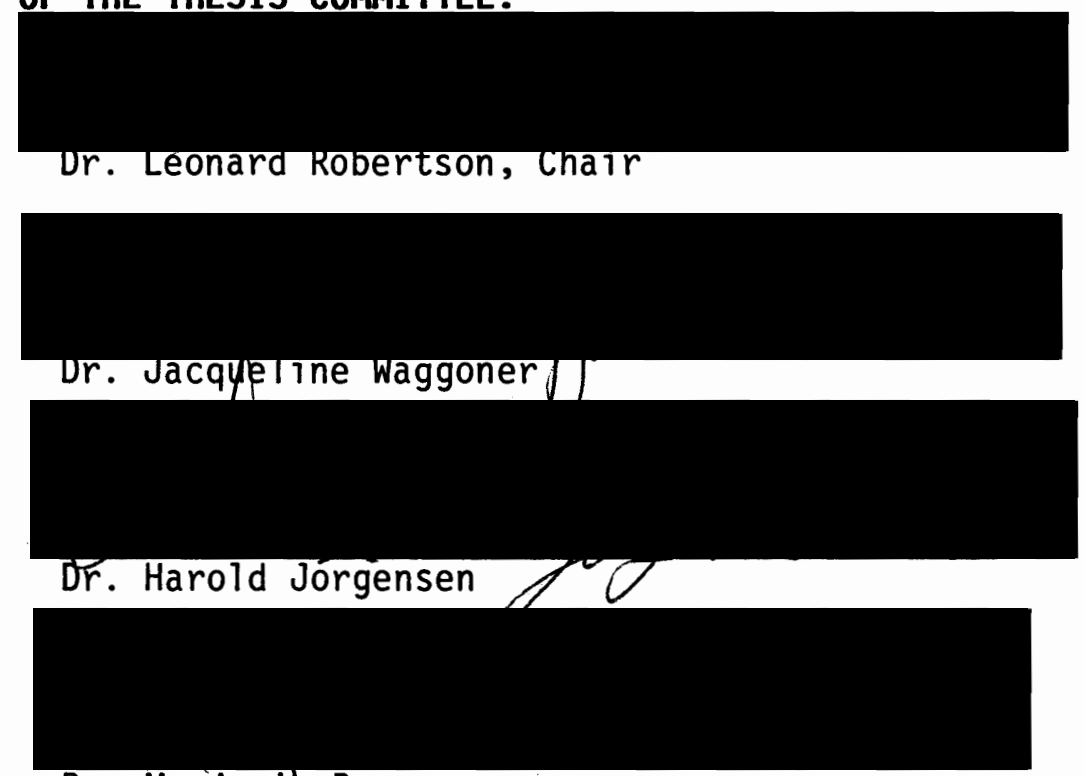

Dr. Marjorig Burns

This study was conducted to determine whether there was a significant difference between the development of speed and accuracy on a 10-key pad on a microcomputer or on an electronic calculator. A total of 204 participants were involved in the quasi-experiment.

The hypotheses tested were:

1. There was no significant difference in the time required to input the digits on the electronic calculator and the microcomputer. 
2. There was no significant difference between the accuracy rates on the microcomputer or the electronic calculator.

The results of the quasi-experiment showed more problems were completed on the electronic calculator from the pre-test to the post test and that the accuracy improved. Even though the participants on the microcomputer input fewer total problems their overall accuracy improved at a greater rate.

The results of the pre-test showed a difference in accuracy between the electronic calculator and the microcomputer to be $2.3 \%$. The results of the post test showed a difference in accuracy of $1.3 \%$. The hypotheses were accepted.

The general conclusion of the study was that it does not make any difference whether the 10-key skill is taught by using an electronic calculator or a microcomputer. 


\title{
A STUDY USING THE 10-KEY PAD \\ ON A MICROCOMPUTER \\ AND \\ ELECTRONIC CALCULATOR
}

\author{
by \\ NANCY $K$. PECHMAN

\section{A THESIS SUBMITTED IN PARTIAL FULFILLMENT OF THE REQUIREMENTS FOR THE \\ DEGREE OF} \\ MASTER OF SCIENCE \\ IN \\ TEACHING \\ IN \\ BUSINESS EDUCATION
}

PORTLAND STATE UNIVERSITY

1985 


\section{ACKMONLEDGEMENT}

The writer wishes to express appreciation to the many people who assisted and contributed to this study. Special recogition to Dr. Leonard Robertson who was chairperson of the writer's supervisory committee, for his help and encouragement throughout this study. The writer is also grateful to Drs. Jacqueline Waggoner, Harold Jorgensen, Marjorie Burns, and Jim Heath who were members of the writers supervisory committee.

Appreciation is extended to Battle Ground School District employees and students at both Prairie and Battle Ground High School who participated in the study.

Nancy K. Pechman 
TABLE OF CONTENTS

PAGE

ACKNOWLEDGEMENT . . . . . . . . . . . . . . . .

LIST OF TABLES ...................... vi

CHAPTER

I INTRODUCTION .................. 1

Need For the Study

Statement of the Problem ........ 2

Purpose of the Study

Delimitation ........... 3

Limitations

Definition of Terms ......... 4

Summary

II REVIEW OF THE LITERATURE . . . . . . . . 5

Introduction

Teaching Methods and Time Needed

Left Hand vs. Right Hand . . . . . . . 6

Men vs. Women ........... . 7

Math and Science

Summary 
III DESCRIPTION OF THE PROBLEM . . . . . . . . 9

Introduction

Research Technique

Refining of Instruments ....... 10

Selection of the Sample

Treatment of Data.......... 11

Summary . . . . . . . . . . 12

IV FINDINGS ................ . . 13

Introduction

Sample Used

Set Up

Rooms

Electronic Calculator

Microcomputer

Treatment of the Data ........ 15

Summary ............. . . 26

$\checkmark$ SUMMARY AND RECOMMENDATIONS . . . . . . . . 29

Summary of Purpose and Procedures

Summary of Findings . . . . . . . . 30

Concluding Statement and Recommendations

BIBLIOGRAPHY .................. . . 32

APPENDIX .......................... 34

Appendix A ................ 35

Appendix B ................ . . 38

Appendix C . . . . . . . . . . . . . 54 


\section{LIST OF TABLES}

TABLE

PAGE

I Pre-test results for Prairie High School . . . . . . . . . 17

II Pre-test results for Battle Ground High School . . . . . . . 18

III Post Test results for Prairie High School . . . . . . . . 19

IV Post Test results for Battle Ground High School . . . . . . 20

$\checkmark$ Combined results of findings from both high schools . . . . 21

VI Analysis of covariance, post test adjusted means of the group ................... . 23

VII Speed and accuracy distribution rates . . . . . . . . 24

VIII Compiled results of all participants from both high schools

on the pre and post tests based on the number of problems completed and answered correctly .......... 25

IX Pre-test results based on the percentage correct during each class period ................... . . . . .

$X$ Post test results based on the percentage correct during each class period . . . . . . . . . . . . . . 28 


\section{CHAPTER I}

\section{INTRODUCTION}

The age of computers is upon us, and the use of microcomputers in the classroom is becoming more and more common every year. The students are not just using the microcomputer for playing games but for programming, typing papers, and doing mathematical computations. Having calculator skills is the most common tool in businesses today (Merchant, 1983).

Should the calculator skills be taught on the electronic calculator or on the microcomputer or does it matter? This study helped determine whether there was a difference in skill acquisition between the use of the electronic calculator or the microcomputer 10-key pad.

\section{NEED FOR THE STUDY}

Keyboarding or Data Entry as it is now called as of 1 September 1984 according to the Superintendent of Public Instruction in the State of Washington (Appendix A), is the course taught instead of typewriting. Part of the course specifies every student must have 18 hours of hands-on experience on the microcomputer and learn the 10-key numerical pad. School districts and business education teachers have to buy equipment to meet state guidelines and are faced with the dilemma of teaching on the microcomputer and the 10-key pad. 
Another need for this study was future workers need the skill of touch control on a 10-key pad for future use in mathematical computations for school and on the job. "Both men and women need to develop the ability to solve business problems with a calculator and use a 10-key keyboard with touch control" (Merchant, 1983). Harcharik (1981) goes on to say "addition is a vital process in business, and proficiency in touch addition is most important" (p. 188). One problem was the lack of agreement on the length of time needed to achieve optimum standards.

\section{STATEMENT OF THE PROBLEM}

The problem was to determine the difference on speed and accuracy between input of numerical data with the microcomputer 10-key pad or the electronic calculator. The criterion measure was a set of timed tests given throughout the study.

The hypotheses tested were:

1. There is no significant difference in the time required to input the digits on the electronic calculator and the microcomputer.

2. There is no significant difference between the accuracy rates on the microcomputer or the electronic calculator.

\section{PURPOSE OF THE STUDY}

The purpose of this study was to determine whether business education teachers need to teach the 10-key pad on an electronic calculator, or could they teach the students on the 10-key pad found 
on most microcomputers. The cost of equipment in a beginning keyboarding class could be two pieces of equipment--microcomputers and printers, or up to four pieces of equipment--microcomputers, printers, selectric typewriters, and electronic calculators. Business education teachers needed to know what effect the type of equipment, or lack of equipment, would have on the students' skills.

The quasi-experiment provided necessary information to determine the speed and accuracy on 10-key pads using two different treatments.

\section{DELIMITATIONS}

The experiment was not concerned with the use of the various function keys: $-; \mathrm{x} ; / ; \%$; memory; found on electronic calculators.

This experiment did not determine whether males or females had better finger dexterity on either piece of equipment.

It was not the intent of this experiment to consider the differences in slants of the 10-key pads on the microcomputers and electronic calculators.

In Hulm's study in 1975, he determined that there was no significant difference between the use of the left or right hand to key in the digits. This study was not concerned with handedness.

\section{LIMITATIONS}

Certain limitations are innate to a quasi-experiment. Intact classes were used, eliminating the possibility of randomization. 
The ability to generalize the findings to equipment in this quasi-experiment was limited to the extent that all the electronic calculators are the same model; all the computers are the same make.

\section{DEFINITION OF TERMS}

In order to comprehend certain terms the following are defined: By Touch - A system emphasizing consistent use of the same finger to index a particular digit, while not looking at the keys.

Keyboarding - Is not interpreted as a name change for Typing I. It is the inputting of information by touch on electronic keyboards (typewriters, computers, or calculator) currently on the market.

10-Key Pad - Numbers 0-10 and a decimal point arranged in a pattern and placed in a square on a pad.

\section{SUMMARY}

The problem was to determine if the speed and accuracy on a 10-key pad using an electronic calculator was any different than on a microcomputer 10-key pad. The changes in our society have shown that the computer is here to stay and everyone will be affected. A concern was whether schools used the equipment they now have--typewriters and calculators, or should they buy microcomputers and only use the latter. If so, does this provide students with equivalent speed and accuracy as the calculator? 


\section{CHAPTER II}

\section{REVIEW OF THE LITERATURE}

\section{INTRODUCTION}

Should business educators be concerned with teaching the 10-key pad by touch? The use of the 10-key pad is an important part of the business world and should be taught by touch. But how much time should the business teacher spend on teaching the 10-key pad; should 10-key be a separate class, combined with others, or dropped?

\section{TEACHING METHODS AND TIME NEEDED}

"The most effective way to operate a keyboard is 'by touch'"-without looking (Robinson, 1980, p. 229). Harcharik (1983) goes on to define the touch system as "consistently using the same fingers to index a particular digit, while not looking at the keys" (p.189). To be able to operate a 10-key pad is a very important function and a vital part of the business world. Some teachers don't see the need to teach the 10-key technique, but how are students supposed to learn the 10-key pad if the pad is such an important part of the business world? Merchant (1983) stated if we, the business education instructors, allow students to leave our programs without knowing the basic skills of how to operate a 10-key pad, the public's image of the business education program will decline. 
Hennington's (1983) study shows teacher-paced programs were better than self-paced for speed but the study did not address the amount of time needed. "There is a lack of agreement by business educators as to the amount of time that should be spent teaching the basic skills of office machine operators" (Chase, 1965, p. 1). Even though the dissertation was written almost 20 years ago, the amount of time needed in teaching machines still seems to be a concern of business educators since more and more schools are dropping business machines or are teaching machines with other courses. The Washington Superintendent of Public Instruction, Office of Business and Office, ${ }^{X}$ informed the researcher the office machines class has not been taught as a separate course since the 1980-1981 school year. In 1981-1983 school years, the electronic calculator course was combined with Business Math and called Electronic Math. Therefore, exact number of students in these classes were not available, since course titles have changed during the past five years. "The 'information explosion' has confronted the classroom instructor with the problem of teaching more content in less time" (McKenzie, 1972, p. 7). This could be one of the reasons math and electronic calculators have been combined.

\section{LEFT HAND VS. RIGHT HAND}

A few articles have been written on the use of the left hand vs. the right hand on the calculator (Hulm, 1975; Zahringer, 1971). The use of the left hand or the right hand does not make any difference on speed or accuracy. Neither study mentioned the fact that the function 
keys are on the right hand side of the 10-key pad or which finger(s) to use to strike the function keys.

\section{MEN VS WOMEN}

In Merchant's study in June, 1983, he stated "research indicated women have better dexterity than men" (p. 16). The research he was referring to was not noted in his article, nor was it footnoted.

\section{MATH AND SCIENCE}

None of the articles in math or science (Billings, 1983; Carpenter, 1980; Roberts, 1980; Sircar, 1982-83; and Suydam, 1984) mentioned whether the students were operating the calculators--electronic or hand-held--by touch. Their concerns were whether the students' accuracy was better with a calculator or by doing mathematical computations by paper and pencil method. The researcher wondered if the students' accuracy and speed, would increase if they were using the calculators by touch. Burford (1980) states math should be taught on a calculator or computer pad by touch. Would the math and science teachers realize the need to have students work the 10-key pad by touch? The results of Burford's (1980) study may help the math and science teachers as well as the business education instructors.

\section{SUMMARY}

Having the teacher pace the drills helps on the student's speed. The math and science instructors are worried about how fast students 
work problems and not if the students use the 10-key pad by touch. 


\section{CHAPTER III}

\section{DESCRIPTION OF THE PROCEDURES}

\section{INTRODUCTION}

The methods and procedures describe how this study proceeded. The results of the quasi-experiment may be of benefit to other business education teachers in preparing their courses in using the 10-key pad in the keyboarding course. The results of this study may be of use in developing the curriculum for keyboarding.

\section{RESEARCH DESIGN}

The design used in this study was a quasi-experiment, since the randomization requirement of a true experiment was not met. The researcher used three teachers, two having two classes with an average of 25 students in each class, the other teacher having four classes with an average of 25 students in each class; giving the study a sample size of 204 participants with a total of eight classes. The researcher met with all three teachers and explained the procedures to be used in teaching the 10-key pad; the length of the experiment and the length of time to be used daily; and a copy of the drills to be used (Appendix B \& C). The researcher monitored the procedures to ensure consistency among the teachers. 


\section{REFINING OF INSTRUNENTS}

The students were given three days to learn the 10-key pad. At the beginning of day four, the students were given a pre-test. On days five and seven the participants were given a five-minute test to record their speed and accuracy rates. The interim tests were given for students to check their progress. Class means for speed and accuracy were used instead of individual scores. After the tests, the students were given 15-minutes practice time for further development of speed or accuracy. Day six was used for 20 minutes of drills--no tests were given. On the last day of this experiment, day eight, the students were given the first 15 minutes for practice and the last five minutes were used to administer the post test.

The tests used were taken from Crawford, Pasewark, and Polisky, 1982. The first and last tests were the same in order to hold difficulty and content consistency.

\section{SELECTION OF THE SAMPLE}

The population of students used were selected from the two high schools in the Battle Ground School District in Battle Ground, Washington at Battle Ground High School and at Prairie High School. The two high schools have a total population of 2,510 students in grades 9-12. There were approximately 25 students in each of the eight classes used for a total of 204 participants. The subjects used in this quasi-experiment were assigned to four keyboarding classes in both 
high schools. Although the students were not randomly selected, the two treatment levels--the use of the microcomputer or the electronic calculator--were randomly assigned to the classes. A table of random numbers was used to select the classes for treatment.

Three teachers, two from Praire High School and one from Battle Ground High School, were used in the quasi-experiment. The three teachers; $D, N$, and $P$ were assigned the following teatments during selected periods:

\section{MICROCOMPUTERS}

BG $\quad D$

PR N

$P$
1

3

5

4

\section{CALCULATORS}

4

6

1

3

Counterbalancing was used in the above process. The use of the microcomputer was used first and fifth period to obtain a balance between morning and afternoon classes; visa versa was true of the use of the calculator.

\section{TREATMENT OF DATA}

Pre and post tests class means were computed for all eight classes. The post test means were subjected to an analysis of covariance which was used to analyze the data using the pretest as the covariate. The level of significance between the use of the 10-key pad on the microcomputer or the calculator was set at .05 .

The participants from the two high schools were given five minutes 
to complete 15 problems on both the pre-test and the post test. The pre-test and post test totals for each of the eight classes were computed to show the number of problems correctly done over the total number completed to determine the accuracy rate for each group. The total number of problems completed and done correctly were grouped by the type of treatment level used by the students.

\section{SUMMARY}

A quasi-experiment was done using eight classes with a total of 204 participants from two high schools. The students were given three days to learn the 10-key pad on either the microcomputer or electronic calculator and then given five more days of instruction to work on speed and accuracy. A pre-test and post test was given to each student to be used to analyze the data. 


\section{CHAPTER IV}

\section{FINDINGS}

\section{INTRODUCTION}

The microcomputer versus the electronic calculator, which was the better machine? The teaching of the 10-key pad on the microcomputer or on the electronic calculator does not seem to make a significant difference in the students' accuracy.

\section{SAMPLE USED}

The writer met with the three teachers involved to explain the procedures to be used in teaching the 10-key pad; giving each teacher a copy of the daily lesson plans (Appendix C) and going over all eight days' plans carefully, so each were able to carry out the quasi-experiment in the same manner? There were 204 participants from Prairie and Battle Ground High Schools used in conducting the quasi-experiment. Counterbalancing was done in the selection of time of day for the treatment, using the microcomputer two periods in the morning and two periods in the afternoon; visa versa was true of the electronic calculator.

\section{CLASSROOM ORGANIZATION}

The three teachers who helped with the quasi-experiment had to modify the organization of the classrooms. Both rooms used had 30-36 
selectric typewriters and seven microcomputers. Fifteen electronic calculators were brought in from other rooms to be used. The teaching of the 10-key pad took only 20 minutes of the 55-minute period; the entire class was able to complete the electronic calculator assignment in one day. The classes working on the microcomputers took two days in order for all students to complete their 20-minute lesson. The teachers allowed the students to use either the left or right hand on the 10-key pad since, as was stated earlier, there was no significant difference between the speed and accuracy of the use of either hand. A majority of the students used their right hands.

Electronic Calculator

The participants placed the calculator at a comfortable angle--some having to move the tables away from the walls, since the desks used have typewriters bolted to the desks. The teachers went over the correct finger placement (Appendix C - Day 1 Lesson) and made sure the digits were printed out on the tape. The tape was used so students could check their answers. After the twenty-minute lesson was over, the other half of the students in the room would obtain an electronic calculator and worksheet from another student and would begin working. It should be noted that all students would be listening to the teacher as she explained finger placement each day, so there would be less classroom disruption. Whichever half of the students finished the electronic calculator last the previous day would begin the next day, so there would not be any significant difference between the first part of the period and the last. 
Microcomputer

The number of microcomputers in the classroom was limited to seven due to space and the computer programming class being taught at the same times as Keyboarding.

Before the participants could begin, they typed in the program (Appendix B-program) to add numbers. Once the program was inputted, the teacher would explain finger placement and the use of the enter key. The students were paired up so one student would input the numbers and when the VDT stated "The Total is __," the second student would write down the totals. This was done in order to insure constant speed. After the twenty minute lesson was completed, the two students would exchange places. The group of students not on the microcomputer were placed on the machines the next day, alternating every day.

\section{TREATMENT OF DATA}

There were 102 participants from each high school; 102 students used the electronic calculator, and 102 used the microcomputer. On day four, (Appendix C - Day 4) the 15 problem pre-test was administered. The students were given five minutes to take the test. It was not marked against them if they did not complete all 15 problems. Those on the calculator ran a tape and wrote their answers on an answer sheet after time was called; the microcomputer students had a partner write the responses on the answer sheet. Partnership was done so students would continuously work and not have to continually stop and start.

First and third period students at Prairie used the electronic 
calculators for the quasi-experiment. The students had an accuracy rate of $75.4 \%$ on the pre-test. The fourth and six period participants using the electronic calculator at Battle Ground had a pre-test accuracy rate of $78.6 \%$ which was a difference of $3.2 \%$ between the morning and afternoon classes of the two schools. The fourth and fifth period microcomputer students at Prairie had a $74.3 \%$ accuracy rate on the pre-test; the first and third period students at Battle Ground showed a $75.7 \%$ rating. The difference between the afternoon and morning classes was $1.4 \%$ (See Tables I and II).

The post test, same 15 problems as the pre-test (Appendix B Pre/Post Test), showed an increase in the accuracy rate for every class. The participants from Prairie showed an increase in both the number of problems completed and those problems done correctly (see Tables I, III, and V). The electronic calculator group completed 45 more problems on the post test than on the pre-test but did 73 total problems more accurately showing an increase in accuracy of $6.6 \%$ (Table V). The microcomputer participants also showed an increase in problems completed, total number correctly done and percent of accuracy. The microcomputer group completed 82 more problems and did 126 more problems correctly on the post test with an increase accuracy level of $10.1 \%$.

The post test results from Battle Ground High School showed an increase in accuracy every period but not all classes showed an increase in the number of problems completed and done correctly. Even though the number of problems completed and done correctly by the first period microcomputer students decreased, their accuracy improved by $11.6 \%$ (See Tables II, IV, and V). The other morning microcomputer group 
TABLE I

\author{
PRE-TEST \\ FOR \\ PRAIRIE HIGH SCHOOL
}

1st period - Electronic Calculator

27 Students

$$
\begin{aligned}
& \text { Correct Answers } \\
& \text { Problems Done }
\end{aligned} \quad \frac{230}{309}=74.43 \% \text { Accuracy }
$$

\title{
3rd period - Electronic Calculator
}

22 Students

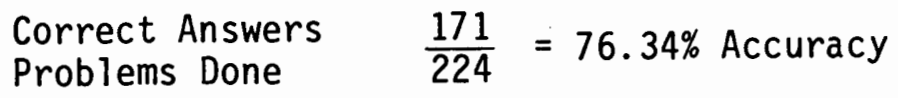

\section{4th period - Microcomputer}

25 Students

Correct Answers

Problems Done

$\frac{196}{273}=71.79 \%$ Accuracy

5 th period - Microcomputer

28 Students

Correct Answers

Problems Done

$\frac{222}{289}=76.82 \%$ Accuracy 


\title{
TABLE II
}

\author{
PRE-TEST \\ FOR \\ BATTLE GROUND HIGH SCHOOL
}

1st period - Microcomputer

25 Students

$$
\begin{aligned}
& \text { Correct Answers } \\
& \text { Problems Done }
\end{aligned} \frac{177}{250}=70.80 \% \text { Accuracy }
$$

3rd period - Microcomputer

24 Students

$$
\begin{aligned}
& \text { Correct Answers } \\
& \text { Problems Done }
\end{aligned} \frac{192}{238}=80.67 \% \text { Accuracy }
$$

\section{4th period - Electronic Calculator}

26 Students

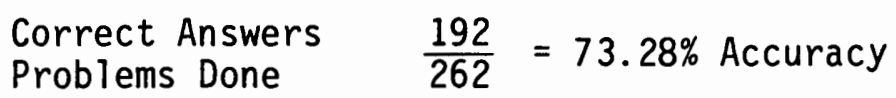

6th period - Electronic Calculator

27 Students

Correct Answers

$\frac{272}{324}=83.95 \%$ Accuracy 
TABLE III

\section{POST TEST \\ FOR \\ PRAIRIE HIGH SCHOOL}

\section{1st period - Electronic Calculator}

27 Students

$$
\begin{aligned}
& \text { Correct Answers } \\
& \text { Problems Done } \\
& \frac{255}{333}=76.58 \% \text { Accuracy }
\end{aligned}
$$

3rd period - Electronic Calculator

22 Students

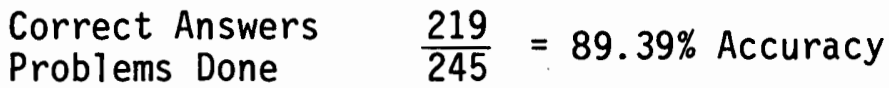

\section{4th period - Microcomputer}

25 Students

$$
\begin{aligned}
& \text { Correct Answers } \quad \frac{265}{307}=86.23 \% \text { Accuracy } \\
& \text { Problems Done }
\end{aligned}
$$

\section{5th period - Microcomputer}

28 Students

Correct Answers

Problems Done

$\frac{279}{337}=82.79 \%$ Accuracy 


\section{TABLE IV}

\section{POST TEST \\ FOR \\ BATTLE GROUND HIGH SCHOOL}

1st period - Microcomputer

25 Students

$$
\begin{aligned}
& \text { Correct Answers } \\
& \text { Problems Done } \\
& \frac{168}{204}=82.35 \% \text { Accuracy }
\end{aligned}
$$

3rd period - Microcomputer

24 Students

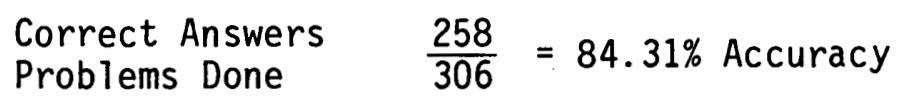

\section{4th period - Electronic Calculator}

26 Students

$$
\begin{aligned}
& \text { Correct Answers } \\
& \text { Problems Done } \\
& \frac{262}{308}=85.06 \% \text { Accuracy }
\end{aligned}
$$

\section{6th period - Electronic Calculator}

27 Students 

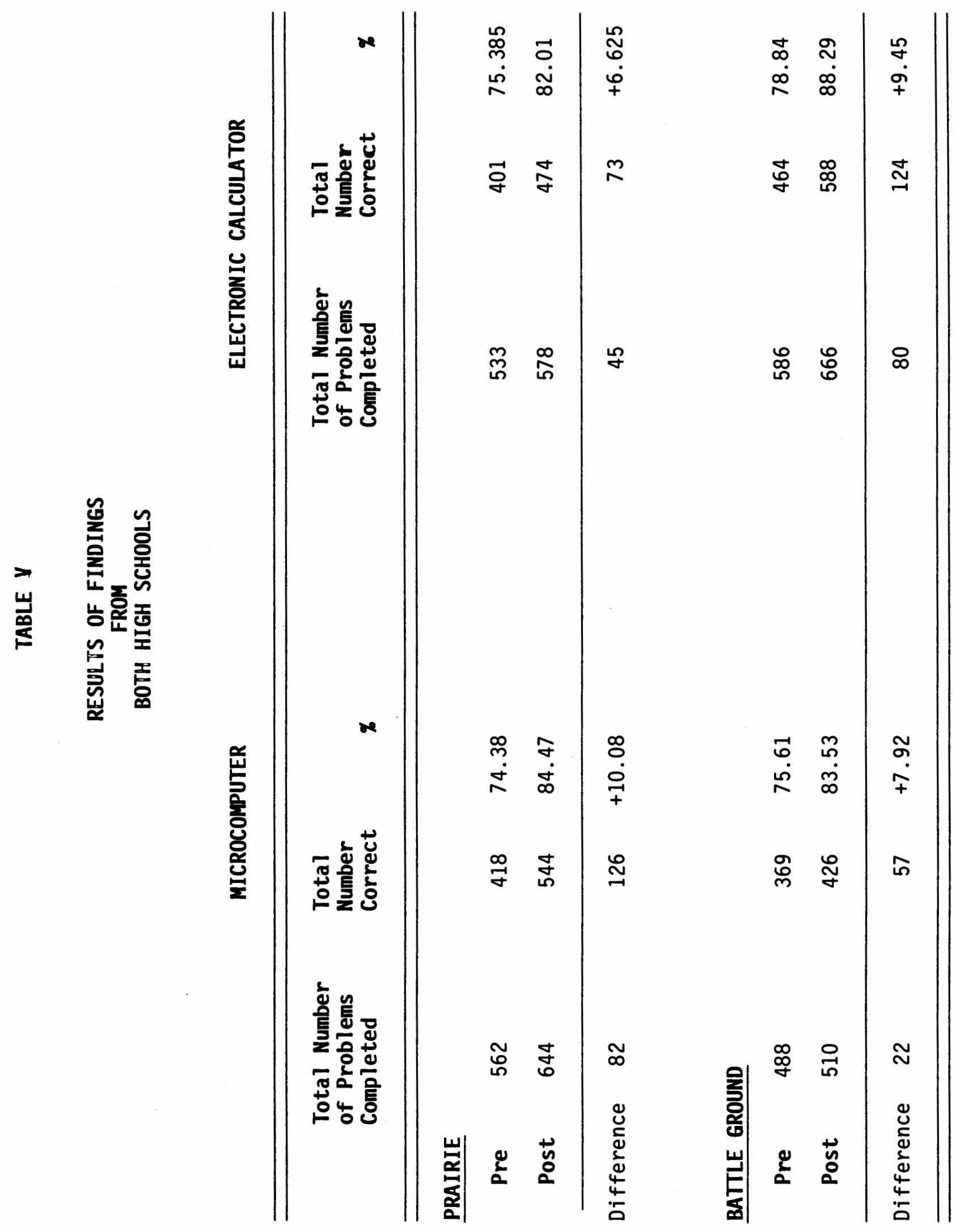
showed an increase in all three areas. Overall, the microcomputer participants completed 22 more problems on the post test and did 57 problems more correctly with a $7.9 \%$ increase in accuracy (Table $V$ ). The afternoon electronic calculator group increased in all three areas: completed 80 more problems, doing 126 more correctly with a $9.5 \%$ increase in accuracy.

The post test speed and accuracy means were subjected to an analysis of covariance using the related pre-test as a covariate. The covariate analyzes showed no significant initial differences between the groups. Table VI shows the analyzes of the groups adjusted means. With alpha set at .05 , both hypotheses of no differences were accepted.

A breakdown of each group's speed and accuracy distribution is illustrated in Table VII. The electronic calculator participants showed an average increase in speed of 1.2 more problems from the pre-test to the post test. The accuracy mean rate increased by 2.1 problems on the average for the 102 students. The microcomputer participants also showed a mean increase in both speed and accuracy of 1.2 and 1.8, respectively. The total population's post test accuracy rate was 10.02 problems correctly done in the 15 minute time limit. On the average 11.77 problems were done by the participants. The electronic calculator group had slightly higher speed and accuracy rates than the microcomputer group, but the difference could be due to chance.

Table VIII shows the compiled results of all 204 participants on the pre-test and post tests. The electronic calculator pre-test shows the 102 students did a total of 1,119 problems with 865 done 
TABLE VI

ANALYSIS OF COVARIANCE

POST TEST ADJUSTED MEANS

OF THE GROUPS

\begin{tabular}{|c|c|c|c|c|}
\hline Hypotheses & $\begin{array}{l}\text { Adjusted } \\
\text { Micro }\end{array}$ & $\begin{array}{r}\text { Means } \\
\text { Calc }\end{array}$ & $F$ & $p$ \\
\hline Speed & 11.53 & 12.01 & 2.742 & .099 \\
\hline Accuracy & 9.68 & 10.36 & 3.755 & .054 \\
\hline
\end{tabular}


TABLE VII

SPEED AND ACCURACY DISTRIBUTION

ON THE

PRE AND POST TEST

FOR THE

\section{ELECTRONIC CALCULATOR AND MICROCOMPUTER}

\begin{tabular}{lccccc}
\multicolumn{5}{c}{ S P E E D } \\
Calculator & $\overline{\mathbf{X}}$ & Mdn & Mode & Stnd Dev. & Stnd Error \\
Pre & 10.980 & 10.500 & 10.00 & 2.371 & .235 \\
Post & 12.196 & 12.154 & 12.00 & 2.000 & .198 \\
& & & & & \\
Microcomputer \\
Pre & 10.176 & 10.155 & 10.00 & 2.423 & .240 \\
Post & 11.353 & 11.556 & 12.00 & 2.586 & .256
\end{tabular}

A C C U R A C Y

Calculator

$\begin{array}{lrrrrr}\text { Pre } & 8.412 & 8.367 & 10.00 & 3.000 & .297 \\ \text { Post } & 10.539 & 10.722 & 12.00 & 2.654 & .263\end{array}$

Microcomputer

$\begin{array}{llllll}\text { Pre } & 7.716 & 7.889 & 8.00 & 2.993 & .296 \\ \text { Post } & 9.510 & 9.750 & 9.00 & 3.136 & .311\end{array}$


TABLE VIII

\section{COMPILED RESULTS \\ OF \\ ALL PARTICIPANTS}

\section{PRE-TEST}

\section{Electronic Calculator}

Answers Correct
Problems Completed $\frac{865}{119}=77.30116 \%$

\section{POST TEST}

$\begin{aligned} & \text { Answers Correct } \\ & \text { Problems Completed }\end{aligned} \frac{1062}{1244}=85.36978 \%$
Microcomputer

Answers Correct
Problems Completed $1057=74.9524 \%$

Answers Correct

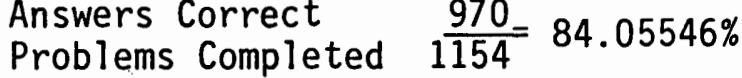


correctly. Those same 102 students did 1,062 problems correctly on the post test out of 1,244 problems answered. This shows an increase of $8.1 \%$ in accuracy. The microcomputer pre-test group did 787 problems correctly out of 1,050 answered. On the post test, the 102 microcomputer students completed 1,157 total problems with 970 done correctly. The increase in problems correctly done from the time of the pre-test to the post test was up $9.1 \%$. The difference in overall accuracy between the electronic calculator group and the microcomputer group was $1.0 \%$.

The percentage of answers correctly done on the pre-test and post test by class periods is shown graphically on Tables IX and $X$. Every period increased their accuracy from the pre-test to the post test. The fourth period microcomputer group showed the greatest increase of $14.44 \%$ with the third period electronic calculator group close behind with an increase of $13.05 \%$.

\section{SUMMARY}

The findings show that there was less than a $2 \%$ difference in accuracy between the electronic calculator participants and the microcomputer participants. Also, both groups were given the same amount of time to input the digits with both participating groups increasing their number of digits entered and correctly completed (Table VII). Therefore, the hypotheses were accepted, since there is no significant difference between the speed and accuracy rates of the two groups. 
TABLE IX

PRE-TEST

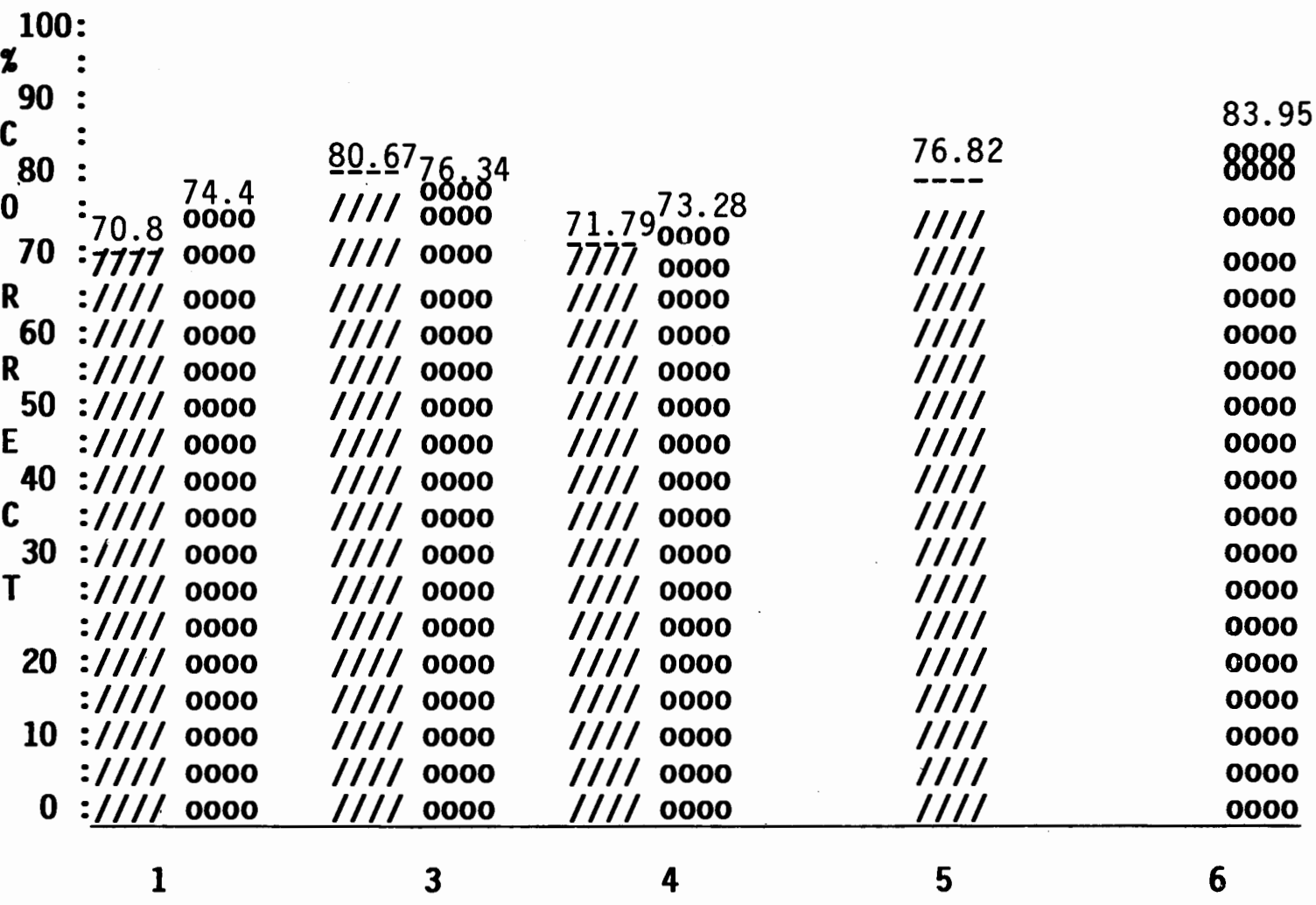

Class periods in a day

$\begin{array}{ll}\text { /l// } & 0000 \\ \text { Micro } & \text { El. Calc. }\end{array}$ 
TABLE $X$

POST TEST

100:

$\%$ :

90:

C $: 82.35$

89.39

84.310000
0000

0 : //// $0000 \quad / / / / 0000$

70: //// $0000 \quad / / / / 0000$

R : //// $0000 \quad / / / / 0000$

60: //// $0000 \quad / / / / 0000$

R : //// $0000 \quad / / / / 0000$

50: //// $0000 \quad / / / / 0000$

E : //// $0000 \quad / / / / 0000$

40: $/ / / / 0000 \quad / / / / 0000$

C : //// $0000 \quad / / / / 0000$

//// 0000

30: $/ / / / / 0000$

11110000

$\mathrm{T}: / / / / 0000$

20: $/ / / 10000 \quad / / / 10000$

: //// $0000 \quad / / / / 0000$

10: //// 0000 //// 0000

: //// $0000 \quad / / / / 1 / / / 000$

$0: / / / / 0000 \quad / / / / 0000$

1

3

4

86.238506

//// 0000

//// 0000

//// 0000

//// 0000

//// 0000

//// 0000

l/I/ 0000

//// 0000

//// 0000

//// 0000

//// 0000

//// 0000

//// 0000

//// 0000

/I/I 0000

//// 0000

82.79

91.06

0000

0000

0000

0000

0000

0000

0000

0000

0000

0000

0000

0000

0000

0000

0000

0000

0000

0000

0000

//// 0000

IIII

6

Class Periods in a Day

$\begin{array}{ll}l / l / & 0000 \\ \text { Micro } & \text { El. Calc. }\end{array}$ 


\section{CHAPTER V \\ SUMMARY AND RECOMMENDATIONS \\ SUMAMARY OF PURPOSE AND PROCEDURES}

As computers become more and more prevalent in society it is important to have proper skills and techniques to input or retrieve data. The writer focused on the use of the 10-key pad--should it be taught on a microcomputer or on an electronic calculator. Future workers need the skills of touch control on the 10-key pad for use in mathematical computations at home or on the job.

The purpose of this study was to determine whether business education teachers need to teach the 10-key pad on a microcomputer or on an electronic calculator. Since most school districts cannot afford to buy all new equipment, could the district make do with whatever type of equipment they possessed in order to train their students for employability.

The writer was able to use students from the Battie Ground School District to participate in the quasi-experiment. The students were given three days to learn the 10-key pad; half of the students on electronic calculator; the other half on microcomputers with pads. On the fourth day, the students were given a five-minute pre-test to record their speed and accuracy rates; the next three days were used for drill practice on speed, accuracy or both. On the last day, day eight, the participants were given a post test to check their speed 
and accuracy.

A total of eight classes were used in the quasi-experiment. The use of the microcomputer and electronic calculator were randomly assigned to the classes with counterbalancing done to control for possible difference in time of day.

\section{SUMMARY OF FINDINGS}

The 204 participants; 102 from each high school; and 102 students each used one of the two treatments, showed no significant difference between the 10-key pads on a microcomputer or an electronic calculator. Each group increased their accuracy from the pre-test to the post test. The microcomputer group from Prairie increased their accuracy by $10.08 \%$; the Battle Ground microcomputer group increased by $7.92 \%$. The increase in accuracy was just as apparent on the electronic calculator with the Battle Ground group increasing 9.45\% and the Prairie group up $6.63 \%$. The difference in overall accuracy and speed between the microcomputer and the electronic calculator shows an increase in favor of the calculator group but the differences were not statistically significant at the .05 level (Table VII).

\section{CONCLUDING STATEMENT AND RECOMMENDATIONS}

The results of this quasi-experiment indicates there were not significant differences in the post test speed and accuracy of the treatment groups. Therefore, the hypotheses were accepted. Although the analyzes of covariance tend to support the group that learned on 
the electronic calculator, the practical significance is minimal. Based on this study, 10-key pad operation can be taught equally well using either the microcomputer pad or the electronic calculator pad with no significant differences in skill acquisition in respect to speed and accuracy.

The writer recommends that a 10-key pad should be included in the course curriculum of Keyboarding with subsequent practice and review in advanced Keyboarding. The use of the function keys should also be taught in advanced Keyboarding so the students have a well rounded ability to operate any type of calculator. The ability to operate the 10-key pad by either hand should be up to the individual since research, as noted in this study, shows there is no significant difference. 


\section{BIBLIOGRAPHY}

Billings, K., "Question and Answer: Typing vs Keyboarding," Arithmetic Teacher, The National Council of Teachers of Mathematics, Virginia, February 1983, Vol. 30, No. 6, pp. 18-19+.

Burford, Anna, "Keyboarding: An Important Skill for the Office of the Future," Journal of Business Education, April 1980, Vol. 55 , pp. $290-293$.

Carpenter, Thomas P., et all, "Calculators and Computers," Mathematics Teacher, December 1980. Vo1. 73, No. 9, pp. 669-673.

Chase, Dayton K., "A Study to Identify the Basic Skills Needed With Adding and Calculating Machines for Office Positions with Implications for Improvement of Instruction in Office Machines." University of Morth Dakota, Ed. D. 1965.

Crawford, K., Pasewark, W., Polisky, M., Solving Business Problems on the Electronic Printing Calculator, 5th edition, 1982, Southwestern Publishing p. 174.

Harcharik, Kathleen, "Teaching the Correct Use of the Electronic Calculator," Journal of Business Education, February 1983, Vol. 56, No. 5, pp. 187-190.

Hennington, Jo Ann, "A Comparative Study of Different Teaching Strategies on the Skill Achievement of Ten-Key Data Entry Keyboarders," MABTE Review, Issue No. 10, A Journal of the National Association for Business Teacher Education, November 1983, pp. 17-22.

Hulm, Lee N., "The Effect of Left-and Right-Handed Operation Of Machines on Speed and Accuracy Achievement in College Office Machines," Business Education Forum, October 1975, Vol. 30, No. 1, pp. 39-49.

McKenzie, Jimmy C., "A Comparison of Two Methods of Teaching the Manipulative Skill of Office Machines," North Texas State University, PHD 1972.

Merchant, Ronald, "Overcoming Math Avoidance Tendencies," Business Education Forum, March 1983, Vol. 37, No. 6, pp. 3-6.

Merchant, Ronald, "Business Students Need Number and Calculator Skills," Compass, June 1983, Vol. 48, No. 6, pp. 3-6. 
Roberts, D. M., "The Impact of Electric Calculators on Educational Performance," Review of Educational Research, Spring 1980, Vol. 50, No. 1, pp. 71-98.

Robinson, Jerry W., Johnson, Gary, "Learning Microcomputer Keyboarding," Balance Sheet, March 1980, Vol. 63, No. 5, pp. 228-231.

Sircar, S., "Microcomputer Support for the Business Data Processing Course," Journal of Educational Technology Systems, 1982-83, Vol. 11, No. 3, pp. 259-64.

Suydam, Marilyn N., "What Research Says: Microcomputers and Mathematical Instruction," School of Science and Mathematics, April 1984, Vol. 84, No. 4, pp. 237-243.

Zahringer, Joseph W., "An Experimental Study to Determine the Effectiveness of Left-Handed Operation on the Ten-Key Keyboard," Business Education Forum, October 1971, Vol. 27, No. 1, p. 57.

Telephone Conversation with SPI Office, Business and Office Division, Robert Langang, OIympia, WA

Interview with Robert Risinger, Vocational Director, Battle Ground School District, Battle Ground, WA 
APPENDICES 
APPENDIX A

Memo From Superintendent of Public Instruction 
May 22, 1984

TO: Vocational Directors/Administrators of School Districts Operating Approved Business \& Office Training Programs

FROM: Bruce Brennan, Assistant Superintendent

Division of Vocational-Technical \& Adult Education Services

RE: $\quad$ Revised Criteria for Keyboarding/Typewriting Course (Data Entry)

After consultation with a field committee, we are taking the keyboarding/ typewriting course off of the pilot status and treating it as any other approved vocational business \& office course with the name changed to "Data Entry" starting September 1, 1984.

The criteria has been modified as reflected below. This criteria will apply to all courses approved under the title of "Keyboarding."

\section{CRITERIA}

Uata Entry will be vocationally supported to a level of 90 enrollment hours of the 180 hour course. This student count will not exceed the number of average yearly unduplicated students enrolled in the first full year courses for one of the business \& office sequences. These courses are: Bookkeeping - 1st year (Bookkeeper sequence) and Advanced Typing for the sequences of Secretary, Clerk Typist, General Office Clerk \& Stenographer.

Example:

A. *Students enrolled in

1. Advanced typing (180 hours)

2. Bookkeeping ( 180 hours)

3. Total unduplicated count

160 students

40 students

200 students $\times 180$ hours $=$ vocational enroliment hours

B. *Students enrolled in

1. Data Entry (180 hours)

400 students

2. Maximum allowable

200 students $\times 90$ hours $=$ vocational enrollment hours

The vocational count of unduplicated students in line B. 2 cannot exceed the unduplicated student count in line A.3. 
Page 2

May 22, 1984

Schools must provide 18 hours of hands-on instruction on a micro-computer for each student enrolled (1 micro-computer for each five students).

Each district will maintain on file a statement of each student's intent (see example A.3 above) that the student is pursuing one of the business \& office program occupational objectives (those students who are enrolled in an advanced typing or lst year bookkeeping course).

IN THE PROGRAM PROPOSAL:

The local district will provide a statement of assurance that the number of students claimed (B.2) for vocational data entry hours will not exceed the number of students the district can verify as being enrolled (A.3) in the business \& office sequence for the year being reported.

COURSE CURRICULUM:

The data entry course curriculum should clearly show that it is vocational preparation in one of the following occupational areas: bookkeeper, secretary, clerk typing, general office clerk and/or stenographer. Course objectives must include, but are not limited to:

Demonstrating the correct "touch" system techniques for operating the alphanumeric keys.

Demonstrating the correct "touch" technique to be used on a ten-key numerical pad.

Demonstrating a straight copy speed of 25 words per minute and an accuracy level of not more than two errors per minute.

Demonstrating the ability to work from typed and rough draft material.

Demonstrating the ability to detect and correct errors in completed work (proofreading).

Demonstrating the ability to follow oral and written directions.

Demonstrating the ability to backspace and correct errors.

Transferring the "touch" system of data entry skills for most of the electronic, automatic, repetitive keyboards currently on the market.

If you have any questions, please call Jay Wood at (206) 753-2062/SCAN 234-2062.

$B B: J W: 1 \mathrm{kh}^{-}$ 


\section{SКәУ lәMSUY pur 'SLL!dO}

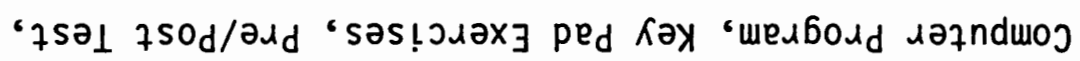

g XIONGddV 
PROGRAM TO TYPE IN ON THE COMPUTER TO DO THE CALCULATIONS

\author{
10 FOR $X=1$ TO \\ 20 INPUT "ENTER A NUMBER"; N \\ $30 S=S+N$ \\ 40 NEXT $X$ \\ 50 PRINT \\ 60 PRINT "YOUR TOTAL IS"; S \\ $70 \mathrm{~s}=0$ \\ 80 GO TO 10
}


LEARNING TO OPERATE 10-KEY PAD

Enter Data Using Home Keys: 4, 5, 6, \& 0

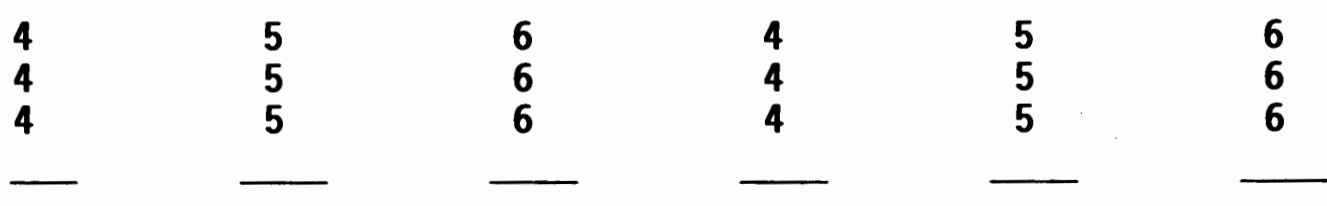

\begin{tabular}{llllll}
44 & 55 & 66 & 44 & 55 & 66 \\
44 & 55 & 66 & 44 & 55 & 66 \\
44 & 55 & 66 & 44 & 55 & 66 \\
\hline
\end{tabular}

\begin{tabular}{llllll}
44 & 45 & 54 & 44 & 55 & 66 \\
55 & 56 & 46 & 45 & 54 & 65 \\
66 & 64 & 65 & 46 & 56 & 64 \\
\hline
\end{tabular}

\begin{tabular}{llllll}
40 & 50 & 60 & 400 & 500 & 600 \\
40 & 50 & 60 & 400 & 500 & 600 \\
40 & 50 & 60 & 400 & 500 & 600 \\
\hline
\end{tabular}

\begin{tabular}{llllll}
40 & 400 & 404 & 406 & 450 & 650 \\
50 & 500 & 505 & 506 & 540 & 560 \\
60 & 600 & 606 & 606 & 405 & 605 \\
\hline
\end{tabular}


Learning New Keys: 7, 8, 9

\begin{tabular}{llllll}
474 & 747 & 585 & 858 & 696 & 969 \\
747 & 777 & 858 & 888 & 969 & 696 \\
777 & 474 & 888 & 585 & 999 & 696 \\
\hline
\end{tabular}

\begin{tabular}{llllll}
774 & 885 & 996 & 745 & 475 & 754 \\
474 & 585 & 696 & 854 & 584 & 846 \\
747 & $\mathbf{8 5 8}$ & 969 & 965 & 695 & 956 \\
\hline
\end{tabular}

\begin{tabular}{llllll}
470 & 580 & 690 & 770 & 707 & 407 \\
740 & 850 & 960 & 880 & 808 & 508 \\
704 & 805 & 906 & 990 & 909 & 609 \\
\hline
\end{tabular}

\begin{tabular}{llllll}
456 & 407 & 508 & 609 & 804 & 905 \\
789 & 408 & 509 & 704 & 805 & 906 \\
987 & 409 & 607 & 705 & 806 & 907 \\
\hline
\end{tabular}


Learn New Keys: 1, 2, 3

\begin{tabular}{lllllll}
414 & 141 & 525 & 252 & 636 & 363 & 174 \\
141 & 111 & 252 & 222 & 363 & 333 & 285 \\
111 & 414 & 222 & 525 & 333 & 636 & 396 \\
\hline
\end{tabular}

\begin{tabular}{lllllll}
114 & 225 & 336 & 175 & 415 & 184 & 174 \\
411 & 522 & 633 & 284 & 524 & 276 & 258 \\
141 & 252 & 363 & 395 & 635 & 359 & 369 \\
\hline
\end{tabular}

\begin{tabular}{lllllll}
417 & 528 & 639 & 110 & 171 & 471 & 714 \\
147 & 280 & 369 & 220 & 282 & 582 & 850 \\
174 & 285 & 396 & 330 & 393 & 693 & 936 \\
\hline
\end{tabular}

\begin{tabular}{lllllll}
77 & 71 & 401 & 107 & 417 & 147 & 174 \\
88 & 82 & 502 & 208 & 528 & 258 & 825 \\
99 & 93 & 603 & 309 & 639 & 369 & 396 \\
\hline
\end{tabular}

\begin{tabular}{lllllll}
44 & 55 & 66 & 714 & 414 & 525 & 636 \\
14 & 25 & 36 & 825 & 474 & 585 & 696 \\
74 & 85 & 96 & 936 & 400 & 500 & 600 \\
\hline
\end{tabular}


DRILL EXERCISES

\begin{tabular}{rrrrrrr}
557 & 51 & 59 & 35 & 735 & 75 & 145 \\
75 & 115 & 95 & 533 & 159 & 750 & 511 \\
775 & 145 & 559 & 563 & 759 & 577 & 541 \\
$\mathbf{5 4 7}$ & 15 & $\mathbf{6 5 9}$ & $\mathbf{6 3 5}$ & $\mathbf{1 5 3}$ & $\mathbf{5 7 5}$ & $\mathbf{1 7 5}$ \\
774 & 515 & 95 & 53 & 574 & 755 & 15 \\
75 & 551 & 995 & 963 & 75 & 70 & 751 \\
757 & 451 & 595 & 356 & 119 & 147 & 175 \\
747 & 145 & 959 & 335 & 115 & 75 & 515 \\
757 & 541 & 159 & 35 & 91 & 705 & 150 \\
75 & 15 & 519 & 539 & 357 & 177 & 745 \\
\hline
\end{tabular}

\begin{tabular}{|c|c|c|c|c|c|}
\hline $\begin{array}{r}559 \\
95 \\
795 \\
569 \\
779 \\
59 \\
195 \\
795 \\
975 \\
95\end{array}$ & $\begin{array}{r}35 \\
535 \\
563 \\
533 \\
153 \\
365 \\
35 \\
350 \\
350 \\
339\end{array}$ & $\begin{array}{l}15 \\
75 \\
39 \\
10 \\
19 \\
95 \\
79 \\
50 \\
45 \\
59\end{array}$ & $\begin{array}{r}536 \\
13 \\
521 \\
45 \\
234 \\
489 \\
160 \\
274 \\
348 \\
625\end{array}$ & $\begin{array}{l}190 \\
208 \\
306 \\
102 \\
610 \\
902 \\
143 \\
650 \\
277 \\
823\end{array}$ & $\begin{array}{r}963 \\
81 \\
320 \\
894 \\
685 \\
686 \\
274 \\
720 \\
90 \\
902\end{array}$ \\
\hline
\end{tabular}

\begin{tabular}{rrrrrrr}
45 & 470 & 199 & 201 & 255 & 425 & 94 \\
775 & 596 & 3773 & 30 & 375 & 250 & 275 \\
566 & 680 & 288 & 3313 & 25 & 680 & 2360 \\
520 & 1275 & 107 & 827 & 89 & 159 & 280 \\
1125 & 320 & 398 & 932 & 2198 & 950 & 587 \\
89 & 85 & 981 & 370 & 3450 & 690 & 500 \\
325 & 145 & 782 & 172 & 655 & 119 & 980 \\
3450 & 310 & 1100 & 319 & 7 & 964 & 1124 \\
8230 & 950 & 37 & 973 & 5500 & 687 & 163 \\
35 & 365 & 91 & 298 & 1250 & 710 & 91 \\
\hline
\end{tabular}


DRILL EXERCISES

\begin{tabular}{|c|c|c|c|c|c|c|c|}
\hline $\begin{array}{l}14 \\
25 \\
36 \\
74 \\
85 \\
96\end{array}$ & $\begin{array}{l}19 \\
37 \\
18 \\
29 \\
38 \\
27\end{array}$ & $\begin{array}{l}173 \\
291 \\
382 \\
794 \\
326 \\
184\end{array}$ & $\begin{array}{l}1236 \\
4596 \\
7896 \\
5474 \\
2975 \\
8535\end{array}$ & & $\begin{array}{l}1714 \\
2825 \\
3936 \\
7414 \\
8525 \\
9636\end{array}$ & $\begin{array}{l}4174 \\
5285 \\
6396 \\
1400 \\
2500 \\
3600\end{array}$ & $\begin{array}{l}4074 \\
5085 \\
6096 \\
9336 \\
8225 \\
7114\end{array}$ \\
\hline $\begin{array}{r}1 \\
14 \\
174 \\
2 \\
25 \\
285 \\
805\end{array}$ & $\begin{array}{r}3 \\
36 \\
396 \\
906 \\
306 \\
20 \\
50\end{array}$ & $\begin{array}{r}40 \\
50 \\
70 \\
740 \\
360 \\
850 \\
960\end{array}$ & $\begin{array}{l}123 \\
789 \\
321 \\
456 \\
174 \\
285 \\
396\end{array}$ & & $\begin{array}{l}114 \\
225 \\
336 \\
774 \\
885 \\
996 \\
500\end{array}$ & $\begin{array}{l}1004 \\
2005 \\
3006 \\
7004 \\
8005 \\
9006 \\
5005\end{array}$ & $\begin{array}{l}8274 \\
9386 \\
7494 \\
1484 \\
2595 \\
3686 \\
6006\end{array}$ \\
\hline $\begin{array}{l}126 \\
786 \\
324 \\
984 \\
876 \\
216\end{array}$ & $\begin{array}{l}104 \\
205 \\
306 \\
704 \\
805 \\
906\end{array}$ & $\begin{array}{l}107 \\
208 \\
309 \\
407 \\
508 \\
609\end{array}$ & $\begin{array}{r}707 \\
808 \\
909 \\
1700 \\
2800 \\
3900\end{array}$ & & $\begin{array}{l}4400 \\
5000 \\
6600 \\
7000 \\
8800 \\
9000\end{array}$ & $\begin{array}{l}3006 \\
2005 \\
1004 \\
9006 \\
8005 \\
7004\end{array}$ & $\begin{array}{l}1714 \\
2825 \\
3936 \\
7144 \\
8255 \\
9366\end{array}$ \\
\hline $\begin{array}{l}1.40 \\
2.50 \\
3.60 \\
4.70 \\
5.80 \\
6.90\end{array}$ & $\begin{array}{l}17.10 \\
28.20 \\
39.30 \\
74.70 \\
85.80 \\
96.90\end{array}$ & $\begin{array}{l}47.17 \\
58.28 \\
69.39 \\
17.10 \\
28.20 \\
39.30\end{array}$ & & $\begin{array}{l}174.11 \\
285.22 \\
396.33 \\
417.14 \\
528.25 \\
639.36\end{array}$ & & $\begin{array}{l}1477.01 \\
2588.02 \\
3996.03 \\
4174.07 \\
5285.08 \\
6396.06\end{array}$ & $\begin{array}{l}10704.50 \\
17815.70 \\
20808.75 \\
26909.65 \\
30906.25 \\
34259.90\end{array}$ \\
\hline
\end{tabular}


DRILL EXERCISES

\begin{tabular}{rrrrrrr}
5 & 77 & 114 & 5808 & 1936 & 9300 & 6936 \\
46 & 89 & 225 & 3997 & 2825 & 8250 & 3896 \\
3 & 78 & 336 & 9408 & 3796 & 10475 & 7140 \\
17 & 85 & 725 & 5650 & 8625 & 7125 & 4874 \\
28 & 98 & 825 & 3714 & 9436 & 12740 & 2515 \\
\hline
\end{tabular}

\begin{tabular}{rrrrrrr}
99 & 795 & 1581 & 1881 & 2642 & 4573 & 2185 \\
67 & 657 & 1691 & 1991 & 2772 & 4683 & 3274 \\
88 & 234 & 1339 & 2202 & 2992 & 5477 & 9396 \\
96 & 359 & 1221 & 2432 & 3743 & 6409 & 4585 \\
84 & 762 & 1101 & 3303 & 3853 & 6886 & 5872 \\
100 & 485 & 1144 & 4650 & 4714 & 7936 & 6903 \\
\hline
\end{tabular}

\begin{tabular}{llllll}
1077 & 3006 & 5208 & 7104 & 1774 & 7417 \\
1400 & 3609 & 5502 & 8205 & 2885 & 8528 \\
1700 & 3900 & 5205 & 9303 & 3996 & 3936 \\
2008 & 4107 & 6309 & 7407 & 4174 & 3936 \\
2500 & 4400 & 6600 & 8508 & 5285 & 5828 \\
2805 & 1704 & 6900 & 9609 & 6396 & 4717 \\
\hline
\end{tabular}

\begin{tabular}{rrrrrr}
1.4 & 14.00 & 170.40 & 1714.70 & 7410.95 & 1147.74 \\
2.5 & 17.00 & 170.43 & 2825.80 & 8520.55 & 2258.88 \\
3.6 & 25.00 & 250.90 & 3936.90 & 9630.65 & 3369.93 \\
7.4 & 28.00 & 288.50 & 4747.17 & 10585.78 & 7144.74 \\
8.5 & 36.00 & 369.63 & 5878.25 & 11474.85 & $\mathbf{8 2 5 5 . 8 5}$ \\
9.6 & 39.00 & 390.69 & 6969.39 & 12696.95 & 9366.63 \\
\hline
\end{tabular}


PRE/POST TEST

\begin{tabular}{|c|c|c|c|c|c|c|c|c|}
\hline (1) $\begin{array}{l}10 \\
20 \\
30 \\
40 \\
50 \\
60 \\
70 \\
80 \\
90 \\
21\end{array}$ & (2) & $\begin{array}{l}85 \\
82 \\
20 \\
51 \\
30 \\
83 \\
92 \\
76 \\
90 \\
13\end{array}$ & (3) & $\begin{array}{l}51 \\
64 \\
58 \\
30 \\
96 \\
80 \\
10 \\
37 \\
48 \\
10\end{array}$ & (4) & $\begin{array}{l}509 \\
108 \\
800 \\
409 \\
807 \\
502 \\
113 \\
219 \\
206 \\
780\end{array}$ & (5) & $\begin{array}{l}213 \\
502 \\
122 \\
146 \\
151 \\
426 \\
313 \\
617 \\
900 \\
802\end{array}$ \\
\hline- & & - & & - & & - & & - \\
\hline $\begin{array}{l}52 \\
69 \\
31 \\
49 \\
66 \\
29 \\
97 \\
12 \\
10 \\
80\end{array}$ & (7) & $\begin{array}{l}35 \\
51 \\
97 \\
81 \\
20 \\
43 \\
79 \\
26 \\
60 \\
37\end{array}$ & (8) & $\begin{array}{l}43 \\
96 \\
89 \\
27 \\
42 \\
23 \\
64 \\
78 \\
91 \\
10\end{array}$ & (9) & $\begin{array}{l}422 \\
479 \\
588 \\
692 \\
760 \\
657 \\
891 \\
208 \\
696 \\
704\end{array}$ & (10) & $\begin{array}{l}800 \\
213 \\
500 \\
486 \\
370 \\
370 \\
426 \\
895 \\
408 \\
220\end{array}$ \\
\hline - & & - & & 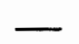 & & & & \\
\hline
\end{tabular}

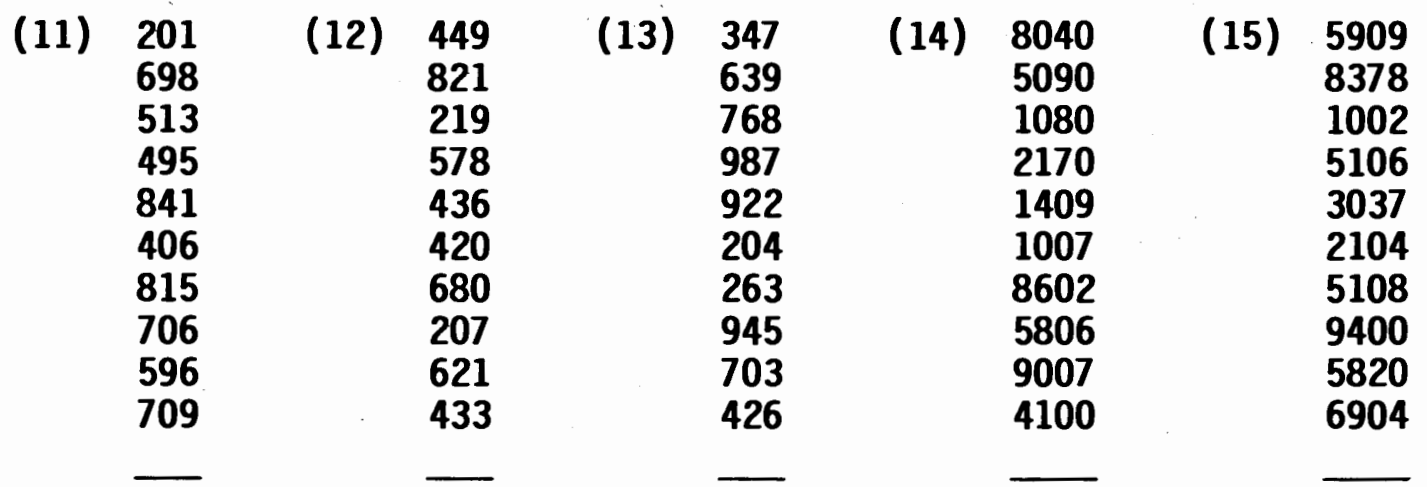




\section{LEARNING TO OPERATE 10-KEY PAD}

Enter Data Using Home Keys: 4, 5, 6, \& 0
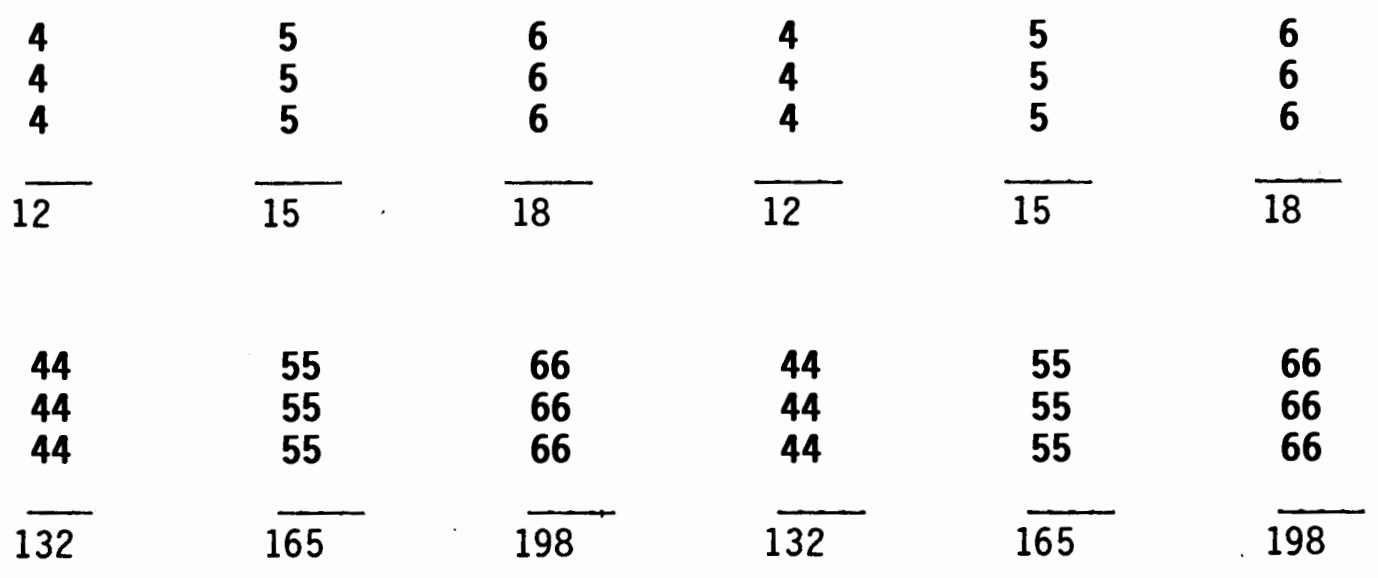

\begin{tabular}{rrrrrr}
44 & 45 & 54 & 44 & 55 & 66 \\
55 & 56 & 46 & 45 & 54 & 65 \\
66 & 64 & 65 & 46 & 56 & 64 \\
\hline 165 & $\overline{165}$ & $\overline{165}$ & $\overline{135}$ & $\overline{165}$ & $\overline{195}$
\end{tabular}

\begin{tabular}{cccccc}
40 & 50 & 60 & 400 & 500 & 600 \\
40 & 50 & 60 & 400 & 500 & 600 \\
40 & 50 & 60 & 400 & 500 & 600 \\
\hline 120 & -150 & 180 & $\overline{1200}$ & $\overline{1500}$ & $\overline{1800}$ \\
& & & & & \\
40 & 400 & 404 & 406 & 450 & 650 \\
50 & 500 & 505 & 506 & 540 & 560 \\
60 & 600 & 606 & 606 & 405 & 605 \\
\hline 150 & -1500 & 1515 & 1518 & -1395 & 1815
\end{tabular}


Learning New Keys: 7, 8, 9

\begin{tabular}{rrrrrr}
474 & 747 & 585 & 858 & 696 & 969 \\
747 & 777 & 858 & 888 & 969 & 696 \\
777 & 474 & 888 & 585 & 999 & 696 \\
\hline 1998 & 1998 & 2331 & 2331 & 2664 & 2664
\end{tabular}

\begin{tabular}{|c|c|c|c|c|}
\hline $\begin{array}{l}774 \\
474 \\
747\end{array}$ & $\begin{array}{l}885 \\
585 \\
858\end{array}$ & $\begin{array}{l}996 \\
696 \\
969\end{array}$ & $\begin{array}{l}745 \\
854 \\
965\end{array}$ & $\begin{array}{l}475 \\
584 \\
695\end{array}$ \\
\hline 1995 & 2328 & 2661 & 2564 & 1754 \\
\hline
\end{tabular}

\begin{tabular}{lrrrrr}
470 & 580 & 690 & 770 & 707 & 407 \\
740 & 850 & 960 & 880 & 808 & 508 \\
704 & 805 & 906 & 990 & 909 & 609 \\
\hline 1914 & 2335 & 2556 & 2640 & 2424 & 1524
\end{tabular}

\begin{tabular}{rrrrrr}
456 & 407 & 508 & 609 & 804 & 905 \\
789 & 408 & 509 & 704 & 805 & 906 \\
987 & 409 & 607 & 705 & 806 & 907 \\
\hline 2232 & 1224 & 1624 & 2018 & 2415 & 2718
\end{tabular}


Learn New Keys: 1, 2, 3

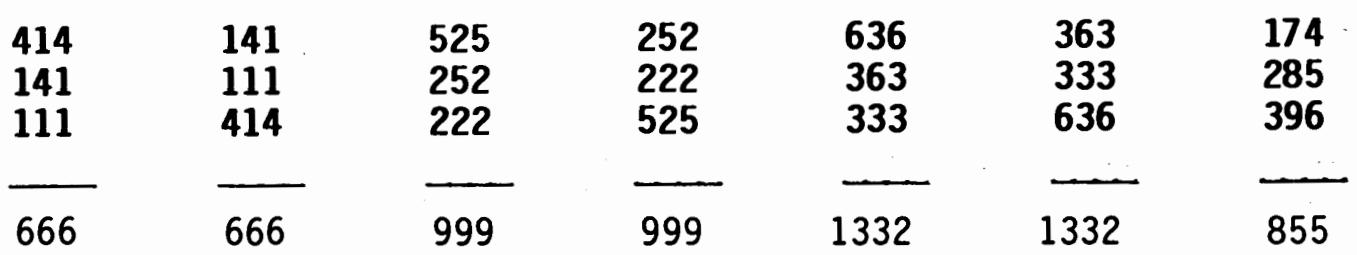

\begin{tabular}{lllllll}
114 & 225 & 336 & 175 & 415 & 184 & 174 \\
411 & 522 & 633 & 284 & 524 & 276 & 258 \\
141 & 252 & 363 & 395 & 635 & 359 & 369 \\
\hline 666 & $\overline{999}$ & $\overline{1332}$ & $\overline{854}$ & $\overline{1574}$ & $\overline{819}$ & $\overline{801}$
\end{tabular}

\begin{tabular}{lrrrrrr}
417 & -528 & 639 & 110 & 171 & 471 & 714 \\
147 & 280 & 369 & 220 & 282 & 582 & 850 \\
174 & 285 & 396 & 330 & 393 & 693 & 936 \\
\hline 738 & 1093 & 1404 & 660 & 846 & 1746 & 2500
\end{tabular}

$\begin{array}{ccccccc}77 & 71 & 401 & 107 & 417 & 147 & 174 \\ 88 & 82 & 502 & 208 & 528 & 258 & 825 \\ 99 & 93 & 603 & 309 & 639 & 369 & 396 \\ \overline{264} & \overline{246} & \overline{1506} & \overline{624} & \overline{1584} & \overline{774} & \overline{1395}\end{array}$

$\begin{array}{rrrrrrr}44 & 55 & 66 & 714 & 414 & 525 & 636 \\ 14 & 25 & 36 & 825 & 474 & 585 & 696 \\ 74 & 85 & 96 & 936 & 400 & 500 & 600 \\ \overline{132} & \overline{165} & \overline{198} & \overline{2475} & \overline{1288} & \overline{1610} & \overline{1932}\end{array}$


DRILL EXERCISES

\begin{tabular}{|c|c|c|c|c|c|c|}
\hline $\begin{array}{r}557 \\
75 \\
775 \\
547 \\
774 \\
75 \\
757 \\
747 \\
757 \\
75\end{array}$ & $\begin{array}{r}51 \\
115 \\
145 \\
15 \\
515 \\
551 \\
451 \\
145 \\
541 \\
15\end{array}$ & $\begin{array}{r}59 \\
95 \\
559 \\
659 \\
95 \\
995 \\
595 \\
959 \\
159 \\
519\end{array}$ & $\begin{array}{r}35 \\
533 \\
563 \\
635 \\
53 \\
963 \\
356 \\
335 \\
35 \\
539\end{array}$ & $\begin{array}{r}735 \\
159 \\
759 \\
153 \\
574 \\
75 \\
119 \\
115 \\
91 \\
357\end{array}$ & $\begin{array}{r}75 \\
750 \\
577 \\
575 \\
755 \\
70 \\
147 \\
75 \\
705 \\
177\end{array}$ & $\begin{array}{r}145 \\
511 \\
541 \\
175 \\
15 \\
751 \\
175 \\
515 \\
150 \\
745\end{array}$ \\
\hline 5139 & 2544 & 4694 & 4047 & 3137 & 3906 & 3723 \\
\hline $\begin{array}{r}559 \\
95 \\
795 \\
569 \\
779 \\
59 \\
195 \\
795 \\
975 \\
95\end{array}$ & $\begin{array}{r}35 \\
535 \\
563 \\
533 \\
153 \\
365 \\
35 \\
350 \\
350 \\
339\end{array}$ & $\begin{array}{l}15 \\
75 \\
39 \\
10 \\
19 \\
95 \\
79 \\
50 \\
45 \\
59\end{array}$ & $\begin{array}{r}536 \\
13 \\
521 \\
45 \\
234 \\
489 \\
160 \\
274 \\
348 \\
625\end{array}$ & $\begin{array}{l}190 \\
208 \\
306 \\
102 \\
610 \\
902 \\
143 \\
650 \\
277 \\
823\end{array}$ & $\begin{array}{r}963 \\
81 \\
320 \\
894 \\
685 \\
686 \\
274 \\
720 \\
90 \\
902\end{array}$ & $\begin{array}{r}817 \\
32 \\
685 \\
148 \\
539 \\
13 \\
650 \\
410 \\
658 \\
561\end{array}$ \\
\hline $4 \overline{916}$ & $3 \overline{258}$ & $\overline{486}$ & $3 \overline{245}$ & $4 \overline{211}$ & $5 \overline{615}$ & $4 \overline{513}$ \\
\hline $\begin{array}{r}45 \\
775 \\
566 \\
520 \\
1125 \\
89 \\
325 \\
3450 \\
8230 \\
35\end{array}$ & $\begin{array}{r}470 \\
596 \\
680 \\
1275 \\
320 \\
85 \\
145 \\
310 \\
950 \\
365\end{array}$ & $\begin{array}{r}199 \\
3773 \\
288 \\
107 \\
398 \\
981 \\
782 \\
1100 \\
37 \\
91\end{array}$ & $\begin{array}{r}201 \\
30 \\
3313 \\
827 \\
932 \\
370 \\
172 \\
319 \\
973 \\
298\end{array}$ & $\begin{array}{r}255 \\
375 \\
25 \\
89 \\
2198 \\
3450 \\
655 \\
7 \\
5500 \\
1250\end{array}$ & $\begin{array}{l}425 \\
250 \\
680 \\
159 \\
950 \\
690 \\
119 \\
964 \\
687 \\
710\end{array}$ & $\begin{array}{r}94 \\
275 \\
2360 \\
280 \\
587 \\
500 \\
980 \\
1124 \\
163 \\
91\end{array}$ \\
\hline 15160 & 5196 & 7756 & 7435 & 13804 & 5634 & 6454 \\
\hline
\end{tabular}


DRILL EXERCISES

\begin{tabular}{|c|c|c|c|c|c|c|}
\hline $\begin{array}{l}14 \\
25 \\
36 \\
74 \\
85 \\
96\end{array}$ & $\begin{array}{l}19 \\
37 \\
18 \\
29 \\
38 \\
27\end{array}$ & $\begin{array}{l}173 \\
291 \\
382 \\
794 \\
326 \\
184\end{array}$ & $\begin{array}{l}1236 \\
4596 \\
7896 \\
5474 \\
2975 \\
8535\end{array}$ & $\begin{array}{l}1714 \\
2825 \\
3936 \\
7414 \\
8525 \\
9636\end{array}$ & $\begin{array}{l}4174 \\
5285 \\
6396 \\
1400 \\
2500 \\
3600\end{array}$ & $\begin{array}{l}4074 \\
5085 \\
6096 \\
9336 \\
8225 \\
7114\end{array}$ \\
\hline 330 & 168 & 2150 & 30712 & 34050 & 23355 & 39930 \\
\hline $\begin{array}{r}1 \\
14 \\
174 \\
2 \\
25 \\
285 \\
805\end{array}$ & $\begin{array}{r}3 \\
36 \\
396 \\
906 \\
306 \\
20 \\
50\end{array}$ & $\begin{array}{r}40 \\
50 \\
70 \\
740 \\
360 \\
850 \\
960\end{array}$ & $\begin{array}{l}123 \\
789 \\
321 \\
456 \\
174 \\
285 \\
396\end{array}$ & $\begin{array}{l}114 \\
225 \\
336 \\
774 \\
885 \\
996 \\
500\end{array}$ & $\begin{array}{l}1004 \\
2005 \\
3006 \\
7004 \\
8005 \\
9006 \\
5005\end{array}$ & $\begin{array}{l}8274 \\
9386 \\
7494 \\
1484 \\
2595 \\
3686 \\
6006\end{array}$ \\
\hline 1306 & 1717 & 3070 & 2544 & 3830 & 35035 & 38025 \\
\hline $\begin{array}{l}126 \\
786 \\
324 \\
984 \\
876 \\
216\end{array}$ & $\begin{array}{l}104 \\
205 \\
306 \\
704 \\
805 \\
906\end{array}$ & $\begin{array}{l}107 \\
208 \\
309 \\
407 \\
508 \\
609\end{array}$ & $\begin{array}{r}707 \\
808 \\
909 \\
1700 \\
2800 \\
3900\end{array}$ & $\begin{array}{l}4400 \\
5000 \\
6600 \\
7000 \\
8800 \\
9000\end{array}$ & $\begin{array}{l}3006 \\
2005 \\
1004 \\
9006 \\
8005 \\
7004\end{array}$ & $\begin{array}{l}1714 \\
2825 \\
3936 \\
7144 \\
8255 \\
9366\end{array}$ \\
\hline 3312 & 3030 & 2148 & 10824 & 40800 & 30030 & 33240 \\
\hline $\begin{array}{l}1.40 \\
2.50 \\
3.60 \\
4.70 \\
5.80 \\
6.90\end{array}$ & $\begin{array}{l}17.10 \\
28.20 \\
39.30 \\
74.70 \\
85.80 \\
96.90\end{array}$ & $\begin{array}{l}47.17 \\
58.28 \\
69.39 \\
17.10 \\
28.20 \\
39.30\end{array}$ & & $\begin{array}{l}174.11 \\
285.22 \\
396.33 \\
417.14 \\
528.25 \\
639.36\end{array}$ & $\begin{array}{l}1477.01 \\
2588.02 \\
3996.03 \\
4174.07 \\
5285.08 \\
6396.06\end{array}$ & $\begin{array}{l}10704.50 \\
17815.70 \\
20808.75 \\
26909.65 \\
30906.25 \\
34259.90\end{array}$ \\
\hline & 342.00 & 260.34 & & 440.41 & 23916.27 & 141404.75 \\
\hline
\end{tabular}


DRILL EXERCISES

\begin{tabular}{rrrrrrr}
5 & 77 & 114 & 5808 & 1936 & 9300 & 6936 \\
$\mathbf{4 6}$ & $\mathbf{8 9}$ & 225 & 3997 & 2825 & $\mathbf{8 2 5 0}$ & 3896 \\
3 & 78 & 336 & 9408 & 3796 & 10475 & 7140 \\
17 & $\mathbf{8 5}$ & $\mathbf{7 2 5}$ & 5650 & $\mathbf{8 6 2 5}$ & 7125 & $\mathbf{4 8 7 4}$ \\
$\mathbf{2 8}$ & $\mathbf{9 8}$ & $\mathbf{8 2 5}$ & $\mathbf{3 7 1 4}$ & $\mathbf{9 4 3 6}$ & $\mathbf{1 2 7 4 0}$ & $\mathbf{2 5 1 5}$ \\
\hline$\overline{99}$ & $\overline{427}$ & $\overline{2225}$ & $\overline{28577}$ & $\overline{26618}$ & $\overline{47890}$ & $\overline{25361}$
\end{tabular}

$\begin{array}{rrrrrrr}99 & 795 & 1581 & 1881 & 2642 & 4573 & 2185 \\ 67 & 657 & 1691 & 1991 & 2772 & 4683 & 3274 \\ 88 & 234 & 1339 & 2202 & 2992 & 5477 & 9396 \\ 96 & 359 & 1221 & 2432 & 3743 & 6409 & 4585 \\ 84 & 762 & 1101 & 3303 & 3853 & 6886 & 5872 \\ 100 & 485 & 1144 & 4650 & 4714 & 7936 & 6903 \\ \overline{534} & \overline{3292} & \overline{8077} & \overline{16459} & \overline{20716} & \overline{35964} & \overline{32215}\end{array}$

1077

1400

1700

2008

2500

2805

$\overline{11490}$

1.4

2.5

3.6

7.4

8.5

9.6

$\overline{33.00} \quad \overline{159.00}$
3006

3609

3900

4107

4400

1704

$\overline{20726}$
5208

5502

5205

6309

6600

6900

$\overline{35724}$

7104
8205
9303
7407
8508
9609

$\overline{50136}$
1774

2885

3996

4174

5285

6396

$\widetilde{24510}$
7417

8528

3936

3936

5828

4717

$\overrightarrow{34362}$
1714.70

2825.80

3936.90

4747.17

5878.25

6969. 39
7410.95

8520.55

9630.65

10585.78

11474.85

12696.95
1147.74 2258.88 3369.93

7144.74

8255.85

9366.63

$\overline{60319.73}$

31543.77 
PRE/POST TEST

\begin{tabular}{|c|c|c|c|c|c|c|}
\hline (1) $\begin{array}{l}10 \\
20 \\
30 \\
40 \\
50 \\
60 \\
70 \\
80 \\
90 \\
21\end{array}$ & (2) $\begin{array}{l}85 \\
82 \\
20 \\
51 \\
30 \\
83 \\
92 \\
76 \\
90 \\
13\end{array}$ & (3) $\begin{array}{l}51 \\
64 \\
58 \\
30 \\
96 \\
80 \\
10 \\
37 \\
48 \\
10\end{array}$ & (4) & $\begin{array}{l}509 \\
108 \\
800 \\
409 \\
807 \\
502 \\
113 \\
219 \\
206 \\
780\end{array}$ & (5) & $\begin{array}{l}213 \\
502 \\
122 \\
146 \\
151 \\
426 \\
313 \\
617 \\
900 \\
802\end{array}$ \\
\hline $4 \overline{71}$ & $6 \overline{22}$ & $4 \overline{84}$ & & $4 \overline{453}$ & & $4 \overline{192}$ \\
\hline
\end{tabular}

(6) 52

69

31

49

66

29

97

12

10

80

495
(7) 35

51

97

81

20

43

79

26

60

37

529
(8) 43

89

27

42

23

64

78

91

10

563
(9) 422

588

692

760

657

891

208

696

704

6097
(10) 800

213

500

486

370

370

426

895

408

220

4688
(11) 201

698

513

495

841

406

815

706

596

709

5980
(12) 449

821

219

578

436

420

680

207

621

433

$\overline{4864}$
(13) 347

639

768

987

922

204

263

945

703

426

$\overline{6204}$
(14)

8040

1080

2170

1409

1007

8602

5806

9007

4100

46311
(15) 5909

8378

1002

5106

3037

2104

5108

9400

5820

6904

52768 


\section{APPENDIX C}

Lesson Plans for Days 1-8 


\section{LESSON PLANS}

\section{DAY 1}

Explain the key pad set up and fingering.

Give each group 20 minutes to operate the 10-key pad on the appropriate equipment.

Explain the set up of the 10-key pad:

$[7]$ [8] [9]

[4] [5] [6]

[1] [2] [3]

[0] [00] [:]---Varies from the computer to the calculator

or

[0] [.] [Ent]/

Home Row: 4 (index), 5 (middle), 6 (ring)

Dot on 5 to help keep fingers in the correct place

Using the Calculator

Press + key after every number.

Press total key $\left({ }^{*}\right)$ for total to print out on the paper.

Print out on the paper so you can double check the answers.

20 Minutes to work on Keys 4, 5, 6, and 0

Go through lst time for accuracy and feel of the fingering; check answers.

Go through again faster, but stay accurate.

If time allows, go through a 3rd time in reverse order.

Using the Microcomputer

Type in program, if it hasn't been previously done. 
Press Enter key after every number. Can use the left hand to press the enter key or use the enter key on the pad.

Answer will appear on the screen.

20 Minutes to work on Keys $4,5,6$, and 0 .

Go through 1st time for accuracy and feel of the fingering; check answers.

Go through again faster, but stay accurate.

If time allows, go through a 3 rd time in reverse order.

When the 20 minute time period is up, switch students from the calculator or microcomputer back to the typewriters and have the other group work on the 10-key pad. 


\section{LESSON PLAN}

\section{DAY 2}

Review previous day's lesson:

Key pad configuration

Fingering--ask the students to demonstrate the placement on the pad.

Remind students to press the + key (or enter key) after each number.

Explain the new keys: $7,8,9$.

Explain the reach used and the proper fingering to be used.

Do 2nd sheet: New Keys 7, 8, 9.

20 minutes time limit.

Do the sheet as many times as time allows.

Remember to check the answers to make sure the right keys are being pressed. 


\section{LESSON PLAN}

\section{DAY 3}

Review previous 2 days' lessons:

Key pad configuration

Fingering

Any reminders/problems that have been noticed from the previous days--keeping fingers on $4,5,6$ keys (home row).

Explain the new keys: $1,2,3$

Explain the technique used to press these lower keys--using the tip of the fingers instead of the pad of the finger that is used on home row. Same technique used when learning the lower keys on the typewriter.

Do 3rd sheet: New Keys 1, 2, 3

20 minute time limit.

Do the sheet as many times as is allowed.

Remember to check answers. 


\section{LESSON PLAN}

\section{DAY 4}

Administer Pre-test:

Students are not to warm-up before.

Hand out the pre/post test papers.

Hand out the answer sheets.

Explain test procedure.

Do as many problems as you can. If you press a wrong number and have already pressed the + or enter key, you can't start over. Finish up that problem and go on.

Calculator students:

Do all the problems in order, printing them out on the paper.

Do not record them on the answer sheet until the timer sounds.

When the timer sounds, tear off the tape, and record the answers on the answer sheet.

Fold the tape so it is approximately the same length as the answer sheet.

Staple the tape to the back of the answer sheet.

Place the answer sheet in the IN BOX and place the test copy on the front desk.

Microcomputer students:

Two students per machine - one taking the test, the other will record the answers on the answer sheet.

Recorder--write down the answers quickly since they do not remain on the screen very long.

When the timer sounds, stop. Recorder will turn in the answer sheet to the IN BOX.

Test taker will turn in test copy to the front desk.

After the first group finishes with the test, administer the test to the second group. Microcomputer pair will exchange places.

After the test:

Do Drill A -- $557+75$ for 15 minutes. Use the same procedure as before. 


\section{LESSON PLAN}

\section{DAYS $5 \& 7$}

Beginning of the 20 minute time period:

Hand out Drill B \& C respectfully

Give students a 5 minute timing

This is for the students' own benefit, not to be graded.

Either write the answers on the board or oral1y give the students the answers so they can check their accuracy.

Rest of the time - 15 minutes:

Have students continue to do the drill exercise 2 or 3 times as time allows.

\section{DAY 6}

No timings

Allow students to work on all three drill sheets on their own. The students may wish to time themselves or each other, which is fine. 


\section{LESSON PLAN}

DAY 8

Before the test:

Allow the students to work on any of the 6 sheets for practice for 15 minutes.

End of the 15 minutes:

Have students hand in all practice sheets.

Hand out the pre/post tests.

Hand out the answer sheets.

Administering Post-test:

Explain test procedure.

Do as many problems as you can. If you press a wrong number and have already pressed the + or enter key, you can't start over.

Calculator students:

Do all the problems in order, printing them out on the paper.

Do not record them on the answer sheet until the 5 minute rings.

When the timer sounds, tear off the tape, and record the answers on the answer sheet.

Fold the tape so it is approximately the same length as the answer sheet.

Staple the tape to the back of the answer sheet.

Place the answer sheet in the IN BOX and place the test copy on the front desk.

Microcomputer students:

Two students per machine - one taking the test, the other will record the answers on the answer sheet.

Recorder --write down the answers quickly since they do not remain on the screen very long.

When the timer rings, stop. Recorder will turn in the answer sheet to the IN BOX.

Test taker will turn in test copy to the front desk.

After the first group finishes with the test, administer the test to the second group. Microcomputer pair will exhange places. 